\title{
PENERAPAN SIMBOL OPERASI MATEMATIKA SEDERHANA SEBAGAI DASAR MENGHILANGKAN ESSENSI BUNGA BANK DALAM PERSPEKTIF ISLAM
}

\author{
Tri Wahyu Budiutomo \\ IKIP PGRI Wates Indonesia
}

\begin{abstract}
According to Islam, bank interest on credit activities is included in the category of "usury" which is forbidden for Islam. The problem of bank credit activities is a very important need for people in doing business. The purpose of this paper is to try to use simple mathematical symbols to try to eliminate the essence of usury.

Changing the essence of "usury" with the concept of cooperation and using a simple symbol " $="$ can eliminate the essence of usury, of course everything must be based on good intentions and honesty.
\end{abstract}

Keywords: bank interest, usury, essence, mathematical symbols "="

\section{A. Pendahuluan}

Pro kontra haram tidaknya persoalan "bunga bank" mengilhami untuk mencoba mengkaji persoalan tersebut. Dalam berbisnis, kalau bisnis kita mulai berkembang, pasti sangat membutuhkan tambahan modal kerja maupun investasi. Kalau kita mau maju, maka hutang untuk bisnis seharusnya bukan suatu masalah, justru sangat perlu ( apalagi kita tidak ada dukungan dana cair, misalnya bantuan saudara, teman atau orang tua ). Hutang di Bank adalah salah satu alternatif. Persoalannya hutang di Bank akan berkaitan dengan " Bunga Bank" dan sementara ini bunga bank masuk "Riba" yang berarti haram .

Sistem bank syariah mencoba menjawab atau mencari solusi, membebaskan bunga bank dari riba. Menarik sekali wawancara dengan Bapak Anang, mantan bankir yang sangat menguasai sistem Bank Syariah, salah satu kelemahan dari sistem syariah adalah pada pelaksanaannya, debitor maupun kreditor kurang memahami inti persoalan dapat terbebasnya bunga bank dari riba. 
Tulisan akan mencoba membahas tentang bunga bank khususnya dalam perspektif Islam. Secara rinci dirumuskan :

1. Apa yang dimaksud dengan "bunga bank"

2. Apakah melalui tinjauan matematis bunga bank dapat bebas dari riba?

\section{B. Teori-teori Tentang Banga Bank dan Hutang}

\section{Bunga Bank}

Bunga bank adalah prestasi yang harus diberikan oleh kreditor pada debitor, dan besarnya dikaitkan pada kesepakatan dan waktu peminjaman. Bunga bank bersifat mengikat dan memaksa.

\section{Pengertian Hutang dalam Perspektif Islam}

Sukarno (2010) Hutang dalam pengertian umum berarti menerima pinjaman dari pihak lain yang harus dikembalikan sesuai dengan perjanjian yang dilakukan setika transaksi (kuliah Hukum Dagang P. Sukarno ). Disampaikan pula bahwa dalah kaidah Fiqih bahwa hutang tidak boleh mendatangkan keuntungan bagi pemberi hutang " bahwa setiap hutang yang membawa keuntungan maka hukumnya riba". Hutang piutang secara islam seharusnya didasarkan pada perintah dan anjuran agama supaya kita dalam kehidupan ini selalu saling tolong menolong serta saling Bantu membantu dalam kebajikan. Hal ini kuatkan dalam

a. Al Qur'an Surat Al Ma'idah ayat 2 :

"Bertolong-tolonglah kamu dalam kebaikan dan dalam melaksanakan takwa, dan jangan kamu gertolong-tolongan dalam dosa dan permusuhan. Bertakwalah kepada Allah. Allah sangat keras hukumannya".

Dengan demikian pemberian hutang atau penerima hutang harus didasari niat tulus sebagai usaha untuk saling tolong menolong sesama dalam kebaikan. Ayat ini berarti bahwa pemberian hutang atau pinjamana pada seseorang harus didasarkan pada pengambilan manfaat dari pekerjaan yang dianjurkan oleh agama atau jika tidak ada 
larangan dalam melakukannya. Karena pemberian utang pada sesama merupakan perbuatan kebajikan, maka seseorang yang memberi pinjaman tidak dibolehkan mengambil keuntungan. Walaupun demikian pemberi pinjaman sudah seharusnya juga tidak dirugikan ?

\section{b. Al Qur'an Surat Al- Baqarah ayat 282}

“Hai orang-orang yang beriman, jika kamu bertransaksi atas dasar utang dalam waktu yang telah ditentukan, tulislah. Hendaklah seorang penulis diantaramu menulis dengan benar, dan janganlah dia enggan menulisnya sebagaimana yang telah diajarkan Allah”

Dalam transaksi hutang piutang Allah telah memberi rambu-rambu agar berjalan sesuai dengan prinsip syariah : yaitu menghindari penipuan dan perbuatan yang dilarang Allah, memberi jaminan kepastian hutang piutang secara tertulis, tentunya sesuai juga dengan hukum dan kebiasaan positif yang berlaku ( misalnya tercacat di Notaris )

c. Al Qur'an Surat Al-Hadid ayat 11 memberi jaminan pada pemberi pinjaman :

“ Barang siapa yang meminjami Allah pinjaman yang baik, Allah akan melipat gandakan baginya dan di sisi-Nya pahala berlimpah dan lebih mulia"

Jaminan ini sangat luar biasa ,khususnya bagi orang Islam yang beriman dan bertakwa, karena jaminan ini membutuhkan niat baik, kejujuran, keyakinan dan ikhlasan.

\section{Fungsi Uang dan Waktu.}

Pada umumnya traksaksi tentang hutang-piutang diwujudkan dalam bentuk “ uang” Apa yang dimaksud dengan uang. Menurut Paul Samoelson dan William D.N. ( 1997) uang adalah alat pembayaran atau alat pertukaran. Dalam perekonomian modern, uang tidak terbatas pada uang logam atau kertas, tetapi juga meliputi cek dan produk perbankan lainnya yang bisa digunakan dalam kegiatan bisnis maupun rumah tangga lainnya.

Uang adalah pelumas yang memudahkan proses pertukaran, karena setiap orang mau menerima uang untuk barang atau jasa yang diberikannya. 
Uang memiliki 2 (dua) nilai, yaitu nilai ekonomi dan nilai riil, dan keduanya dapat tidak sama. Misal: untuk uang Rp ,100.000 kertas, dilihat dari harga barangnya yang berupa kertas murah, namun dilihat nilai ekonominya cukup tinggi, dapat ditukarkan barang yang nilainya lebih tinggi. Lebih-lebih pada era global nilai uang dapat terdepresiasi.

Depresiasi adalah penurunan harga mata uang yang berlaku dipasar, sedangkan kenaikan nilai mata uang disebut apresiasi. Pada saat sekarang ini uang sudah menjadi barang dagangan atau diperdagangkan, sehubungan dengan hal tersebut, waktu merupakan faktor dominan yang sangat mempengaruhi nilai uang, Misal nilai Rp 1 juta pada tahun ini (2020), sangat dimungkinkan akan berbeda nilainya pada tahun 2021. Dan mengingat lenahnya nilai tukar rupiah terhadap mata uang asing, serta kecenderungannya mata uang rupiah kecenderungannya terus selalu terdepresiasi, maka diperkirakan tahun 2022 nilai rupiah akan turun sekitar12 persen , sehingga diperkirakan Rp 1 juta tahun 2021, nilai rupiah pada tahun 2022 sekitar Rp 880.000.

$\mathrm{BI}$ rate biasanya sebagai patokan naik turunnya rupiah. Waktu sebagai fungsi dari nilai uang, naik turunnya nilai rupiah dipengaruhi waktu.

\section{Berwirausaha}

Kewirausahaan sering juga disebut wiraswasta. Wiraswasta berasal dari kata : "Wira" artinya pejuang, teladan, utama, gagah, berani, luhur. "Swa" artinya sendiri. "Sta" artinya berdiri. Jadi wiraswasta mempunyai arti pejuang yang gagah berani, dan luhur, utama yang berusaha berdiri dari kemampuan sendiri. Arti wirausaha juga tidak berbeda dengan wiraswasta yaitu pejuang yang gagah, berani, dan luhur dalam melakukan kegiatan usaha secara mandiri.

Berwirausaha adalah kegiatan usaha perorangan yang diorganisir untuk menghasilkan barang dan jasa guna mendapatkan keuntungan dalam memenuhi kebutuhan masyarakat.

Dalam arti sempit terutama dikaitkan dengan bisnis, wirausaha adalah orang yang berusaha menggunakan uang dan waktu dengan menanggung 
resiko. Berani mengambil resiko serta mampu memperhitungkan dan memanage sehingga menjadi hal yang menguntungkan, dengan kata lain mengubah kendala menjadi peluang. Wirausaha selalu berupaya mencapai dan menghasilkan karya yang lebih baik selangkah lebih maju dari yang lain, dan kesemuanya adalah untuk kepuasan masyarakat khususnya Clien atau customersnya

Dalam buku Kamus Besar Bahasa Indonesia, entrepreneur (wirausaha) berarti orang yang berani mengambil resiko untuk mendapatkan keuntungan, dalam konteks ekonomi. Arti tersebut juga mengandung makna jiwa dan semangat. Artinya sosok wirausaha tidak saja menunjukkan sebuah profesi, melainkan termasuk jiwa dan semangat yang melekat pada profesi tersebut.

Kreativitas dalam mencari, menciptakan peluang ,meningkatkan produktivitas dan efisiensi serta memiliki sifat antisipasi terhadap perubahan akomodatif dari lingkungan merupakan suatu keharusan bagi seorang wirausaha.

Wirausaha akan selalu berusaha meningkatkan keunggulan dan citra diri maupun lembaga melalui investasi maupun produk baru sehingga memiliki ciri khusus yang tidak dimiliki pesaing berpikir makro dalam mengutamakan nama baik. Mampu mengambil keputusan secara tepat dan cepat.

Kegiatan wirausaha bukan merupakan kegiatan yang dilarang agama, secara implisit bahkan dianjurkan oleh agama Islam. Manusia hidup didunia diberi tugas oleh Allah s.w.t sebagai khallifah yang bertugas memelihara, dunia.

Bekerja dalam rangka memelihara dunia dalam kebajikan adalah tugas utama. Rasulullah adalah seorang wirausaha, beliau memberi contoh bagaimana berwirausaha yang islami. Dalam konsepnya Rasulullah, sebagaimana ditulis oleh Syafi'I Antonio pada artikelnya yang menceritakan tentang riwayat Rasulullah yang telah mendapat pendidikan entrepreneur rship sejak usia 12 tahun, ketika bersama pamannya Abu Thalib melakukan perjalanan bisnis. Pada usia 17 tahun beliau telah diberi tanggungjawab untuk mengurus seluruh bisnis pamannya, dan mulai merasakan persaingan dengan para pedagang yang lebih professional. Menginjak usia 25 tahun 
beliau mendapatkan dukungan finansial dari konglomerat Siti Khadijah yang kemudian menjadi istri Beliau.

Aspek-aspek modal dalam bisnis sebetulnya telah diajarkan oleh Rasul 15 Abad yang lalu, lewat sifat-sifat kerasulan yang dimiliki beliau yaitu sidiq (benar), amanah (terpercaya), fathonah(cerdas) dan tabligh (komunikasi). Nilai-nilai moral ini bersifat general truth, melintasi batas waktu, agama, dan budaya.

\section{Pembahasan}

Bunga hutang pada dasarnya hukumnya riba. Hutang pada dasarnya tidak boleh memberikan keuntungan bagi si pemberi hutang, karena setiap hutang yang membawa keuntungan hukumnya riba. Hal ini terjadi jika salah satunya mensyaratkan atau menjanjikan penambahan.

Hutang-piutang harus dapat memberikan banyak manfaat bagi kedua belah pihak, karena hutang adalah merupakan perbuatan saling tolong menolong antara umat manusia yang sangat dianjurkan oleh Allah S.W.T. selama tolong menolong dalam kebajikan

Transaksi hutang-piutang demi untuk kebajikan akan mendatangkan pahala bagi keduanya, niat baik, kejujuran, keseriusan kedua belah pihak merupakan suatu keharusan.

Bunga bank yang sifatnya memberi penambahan hukumnya riba, persoalannya adalah bagaimana apabila pinjaman itu berbentuk uang, dimana fungsi waktu sangat mempengaruhi nilai uang tersebut. Dengan kata lain, apabila waktu pinjaman cukup lama maka nilai uang akan terdepresiasi cukup tinggi sehingga pemberi pinjaman akan rugi.

Apakah kesesuaian nilai uang hingga uang bernilai tetap dalam waktu yang berbeda dapat dibenarkan dalam agama Islam ? Misal: Pada tahun 2021 Si A pinjam pada si B Rp 1 Juta, maka pada tahun 2022 akan sesuai nilainya bila Si B mengembalikan Rp 1 juta ditambah Rp 120.000 sebagai pengganti depresiasi 12 persen per tahun. 
Secara ekomoni kasus ini baru "pas" dalam arti si B tidak dirugikan akibat depresiasi, namun bagaimanapun apabila Rp 120.000 diasumsikan sebagai penambahan dan dikatakan sebagai bunga tetap riba.

Aspek-aspek modal dalam bisnis termasuk secara implisit soal hutang. Walaupun Rasulullah menghindari adanya hutang, salah satu kelemahan hutang bila tidak dimanage dengan baik adalah membuat tidak enak bagi pemberi pinjaman, karena mungkin bisa nggak enak hati bila setelah jatuh tempo/janji pelunasan belum juga dilunasi, sebaliknya bagi peminjam bisa nggak enak bila sampai masa pelunasan belum bisa dilunasi ( Hutang itu bisa membuat sedih di malam hari dan hina disiang hari ).

Sebetulnya telah diajarkan oleh Rasul 15 Abad yang lalu, lewat sifat-sifat kerasulan yang dimiliki beliau yaitu sidiq (benar), amanah (terpercaya), fathonah(cerdas) dan tabligh(komunikasi). Nilai-nilai moral ini bersifat general truth, melintasi batas waktu, agama, dan budaya.

Sehubungan dengan hal tersebut maka hutang-piutang harus benar-benar didasarkan pada kegiatan kebajikan, terpercaya kejujuran merupakan dasar utama pengelolaannya serius dan cerdas dan selalu ada komunikasi yang baik antara keduanya sehingga selalu ada kesamaan paham ( saling mengerti dan memahami )

Konteks tolong - menolong, kerjasama untuk kebaikan merupakan dasar utama dalam hutang piutang. Dalam kaitannya dengan berwirausaha, bunga hutang tetap bersifat riba hukumnya sehingga tidak diperbolehkan. Kerjasama antara pemilik modal dengan pelaksana yang menggunakan modal untuk melaksanakan suatu kegiatan yang didasarkan kebajikan hemat saya dapat diperbolehkan, dengan kata lain untuk berwirausaha hubungan antara pemodal dengan pengelola modal sudah seharusnya bukan merupakan hutang piutang namun kerjasama. Sedangkan hutang-piutang hanya diterapkan pada kasus tolong-menolong karena adanya kesulitan bagi peminjam dan keiklasan serta kemampuan pemberi pinjaman.

Dalam kontek hutang-piutang Bunga bank bersifat riba. Bunga bank diperbolehnka apabila akadnya merupakan kerjasama yang baik, dalam arti 
harus saling ( menguntungkan) bagi kedua pihak. Lebih tepatnya bila bunga bank itu diganti dengan prestasi dari hasil kerjasama. Sebagaiman kita ketahui dalam kegiatan bisnis, terdapat tiga kategori kegiatan yaitu : (1) pencetus ide yang dikenal dengan istilah founder; (2) pemilik dana dikenal dengan istilah owner; dan (3) pengelola kegiatan bisnis dikenal dengan sebutan chief excecutif officer ( manajer ). Ketiga kegiatan tersebut dapat dilakukan oleh satu orang, namun untuk bisnis dalam skala besar biasanya dilakukan oleh beberapa orang.

Pencetus ide atau founders dalam hubungannya dengan pemilik dana (owner) berstatus sebagai kreditor ( penghutang), sedangkan Owner sebagai pemilik dana atau pemberi hutang, mereka kerjasama, dan agar supaya kjegiatan bisnis ( Even organizer atau EO) berjalan lancar kegiatan bisnis tersebut diserahkan pada profesional, chief execcutif officer (CEO).

Prinsip utamanya adalah kerjasama saling tolong-menolong, saling menguntungkan, niat baik dan kejujuran merupakan landasan utama. Persoalan sekarang bagaimana realisasi kerjasama yang menguntungkan tersebut.

Dalam matematika sering digunakan simbol-simbol yang umum dikenal oleh matematikawan. Sering kali pengertian simbol ini tidak dijelaskan, karena dianggap maknanya telah diketahui. Salah satu simbol matematika sederhana " =" kesamaan, sama dengan, umum. $\mathrm{X}=\mathrm{y}$ berarti $\mathrm{x}$ dan y mewakili hal atau nilai sama. Dapat dipergunakan sebagai dasar perhitungan.

Kerjasama antara Founder sebagai pencetus ide bermodalkan karya yang berbentuk ide dengan Owner bermodalkan dana finansial, yang nilai ekonominya dipengaruhi oleh dipresiasi atau upresiasi fungsi uang dan waktu ( nilai ekonomi uang), konsep bunga tidak tepat diterapkan dalam kasus ini, Namun kalau kerjasama terpisah misalnya: Founder yang melaksanakan Even Organizer tanpa keikutsertaan Owner, maka dalam jangka waktu tertentu Founder wajib memberi imbalan atas kerugian terdepresiasinya modal kapitalnya, demikian sebaliknya. Kejujuran merupakan landasan utama.

Contoh :

1. Founder dan Owner mengelola bersama sebuah Even Organize, Keuntungan maupun kerugian ditanggung bersama. 
Founder modal ide $=$ Owner modal finantial seimbang

Misal Ide Founder dinilai $1 \mathrm{M}=$ Owner modal finantial $1 \mathrm{M}$

2. Founder menjual idenya pada Owner, dan Owner mengelola EO sendiri, bisa juga dengan menyerahkan pengelolaannya pada CEO. Founder berhak menerima imbalan dari Owner sesuai kesepakatan atas ide Founder.

Misal ide Founder dinilai $1 \mathrm{M}$, Ide dibayar Owner, tanggungjawab selanjutnya pada Owner.

3. Founder merealisasi idenya sendiri, untuk pelaksnaan menggunakan modal Owner. Founder bertanggungjawab membayar tambahan atas depresiasi maupun upresiasi uang Owner.

Founder bertanggungjawab atas pertambahan dana Owner $1 \mathrm{M}+$ De up = Owner berhak atas $1 \mathrm{M}+$ De up.

\section{Kesimpulan}

1. Bunga bank adalah prestasi yang harus diberikan oleh kreditor pada debitor, dan besarnya dikaitkan pada kesepakatan dan waktu peminjaman. Bunga bank bersifat mengikat dan memaksa.Bunga hutang pada dasarnya hukumnya riba.

2. Hutang pada dasarnya tidak boleh memberikan prestasi atas kerjasama para pihak, yang hasilnya mengikat semua para pihak.keuntungan bagi si pemberi hutang, karena setiap hutang yang membawa keuntungan hukumnya riba. Hal ini terjadi jika salah satunya mensyaratkan atau menjanjikan penambahan.

3. Hutang piutang harus menguntungkan bagi kedua pihak. Bagi peminjam lebih bersifat kegiatan sosial kemanusiaan dan bagi penerima pinjaman merupakan bentuk bantuan dari sesama yang harus dipergunakan secara baik dan dkembalikan tepat waktu.

4. Bunga bank dapat diperbolehkan apabila esensi dasarnya diubah sebagai prestasi atas hasil kerjasama para pihak dan bersifat mengikat para pihak. Dengan kata lain pihak owner misalnya bank dapat juga rugi apabila hasil 
kerjasama ternyata hasilnya rugi tidak hanya untung saja ( dengan menjual jaminan)

5. Penghitungan atas depresiasi maupun apresiasi dihitung secara matematis berdasarkan prinsip BI rate.

\section{Daftar Pustaka}

Al-Qur.an dan terjemahan, Penerbit Asy-Syifa' Semarang, 2001.Kamus Besar Bahasa Indonesia, Depdinas, Jakarta

Purdi E. Chandra (2001), Menjadi Entrepeneur Sukses, PT. Gramedia Widiasarana,Jakarta.

Paul A. Samoelson dan William D.N.(1997), Micro Economic, MC Graw-Hill,Inc. New York

Sukarno (2010), Cacatan Kuliah Hukum Dagang

Syafi'I Antonio (2001), Artikel Konsep Berwiraswasta dalam Islam

Wiki Media, tentang Muamalah 